\title{
Personal and Correspondence Discussion of International Bakhtin Theoretical and Practical Conference "Street Theatre vs. Theatre of the Military Actions"
}

\section{Elena A. Semenova}

Non-Commercial Partnership "THEATRE-EX". Moscow, Russia. Email: semenova05[at]list.ru

Abstract

This work reviews the International Bakhtin Theoretical and Practical Conference "Street theatre vs. the theatre of military actions" held in Moscow in 2019. A review of the collection of articles based on the materials of this conference is given.

Keywords

Bakhtin M. M.; Bakhtin Conference; Street Theater; Book Review; Collection; Theater of Military Operations; Actor 


\section{Очная и заочная дискуссия вокруг Международной Бахтинской научно- практической конференции «Уличный театр против театра военных действий»}

\section{Семенова Елена Александровна}

Некоммерческое партнёрство «ТЕАТР-ЭКС». Москва, Россия. Email: semenova05[at]list.ru

Аннотация

В статье представлен обзор состоявшейся в 2019 году в Москве Международной Бахтинской научно-практической конференция «Уличный театр против театра военных действий». Приводится ревью сборника научных трудов по материалам данной конференции.

Ключевые слова

Бахтин М. М.; бахтинская конференция; уличный театр; обзор; сборник; театр военных действий; актёр

Это произведение доступно по лицензии Creative Commons «Attribution» («Атрибуция») 4.0 Всемирная 


\section{Бахтин и театр (к истории вопроса)}

Главный пафос одной из последних допандемических Бахтинских конференций «Уличный театр против театра военных действий», как представляется сегодня, спустя два года после её проведения, состоял в стремлении избежать заочной, «умерщвляющей» оценки, нередко применяемой в отношении карнавальной культуры, которой, как подсудимому, выносится приговор, который «не предполагает и не учитывает возможный ответ на эту оценку со стороны самого героя» (Бахтин, 2002, с. 83). Организаторы конференции, очарованные уличным театром и Бахтинским карнавалом, предприняли попытку осуществить очный диалог об уличном театре в его присутствии, руководствуясь бахтинским принципом, что «Любовь не говорит о предмете в его отсутствие, а говорит о нем с ним самим» (Бахтин, 1996, с. 66).

Инициатива проведения конференции принадлежит уличному Театру-ЭКС, возникнув, как ответ на потребность практиков уличного театра осмыслить перспективы развития уличного искусства в России сквозь призму категорий карнавальной культуры.

Философия поступка Бахтина и его трактовка народно-смеховой культуры близки труппе театра, поскольку сфера практической деятельности актёров Театра-ЭКС связана с клоунадой, балаганом и карнавалом (Берладин \& Семенова). Труппу Театра-ЭКС можно отнести к неформальному, творческому сообществу, где происходит приобщение актеров к карнавальной культуре и уличному театру. Театр-ЭКС с 2017 по 2020 год активно сотрудничал с ФГБНУ «ИХОиК РАО», проведя совместно ряд бахтинских международных конференций, научно-практических кластеров и семинаров по уличному театру, искусству клоунады и карнавальной культуре в Москве, Орле, Омске, Торопце (Семёнова, 2019, с. 22). На сегодняшний день НП «Театр-ЭКС» активно сотрудничает с Общественной академией эстетики и свободных искусств им. Ю.Б. Борева (Уличный «Театр-Экс»).

«Деревенский театр» является постояннодействующей научно-практической лабораторией Театра-ЭКС, на которой в 2019 состоялся Всероссийский съезд «Смехотворец», приуроченный к 124-летию М.М. Бахтина (11-17 сентября), ежегодный региональный семинар «Уличный театр против театра военных действий» $(2017,2018,2020)$ и др.

Музей, театр, библиотека, улица - вот те подмостки-трибуны, на которых разворачивался диалог участников конференции. Публика: от представителей академической науки до представителей молодежных субкультур и уличного театра.

Официальными партнёрами конференции выступили НП «Культурнопросветительский центр “Булгаковский Дом"», Центральная научная библиотека Союза театральных деятелей РФ, МАНО «Ночные Волки». ФГБНУ «ИХОиК PAO» взял на себя функцию соучредителя и соорганизатора. 
Нужно отметить, что тема конференции актуальна для Российского театрального и искусствоведческого сообщества, поскольку сегодня ощутимо значительное опережение теоретического осмысления бахтинских понятий и существенное отставание их верификации. Кроме того, сами работы Бахтина дают повод либо чрезмерно упрощать концепцию карнавальной культуры, либо неоправданно расширять, усложнять, политизировать её или измерять карнавальный мир театральными мерками. Так, например, «карнавал и революция» является широко обсуждаемой и дискуссионной темой в бахтиноведении. Данной темы касались К. Хиршкоп, К. Хампри, М. Гардинер, М.Д. Бристоль, Б. Гройс, П. Стеллибрас, А. Уайт и др. К. Эмерсон считает, что в Европе особенно популярны те «аспекты бахтинского творчества», в которых карнавал можно интерпретировать как «перманентную революцию и <..> как поле сражения» (2019, с. 22). По мнению К. Эмерсон, данное утверждение в корне не верно.

Несмотря на то, что в российских исследованиях по искусствоведению, театроведению, категории и метафоры Бахтина фигурируют довольно часто, столь привлекательные для театрального тезауруса они, тем не менее, с трудом приживаются в театральной и театроведческой терминологии. Показателем этого может служить история защиты кандидатской диссертации Л.М. Ивлевой, которая видела определённые перспективы применения бахтинской методологии в изучении дотеатрально-игрового языка русского ряженья. Однако во время защиты члены диссертационной комиссии настаивали на трактовке дотеатрально-игровой природы ряженья с помощью более традиционной театральной системы К. С. Станиславского. Возможно до тех пор, пока не появится некоторая чёткая, выстроенная система бахтинских терминов, концептов и понятий, они так и останутся в арсенале личной творческой кухни того или иного исследователя, художника, педагога. Возможно, что в этом и состоит очень деликатный вопрос, касаемый возможности создания театральной педагогики, школы на основе Бахтинской научной картины мира.

Особую актуальность, сложность для театральной педагогики представляют бахтинские положения, изложенные в работах «К философии поступка», «Искусство и ответственность», в которых утверждается, что «за то, что я пережил и понял в искусстве, я должен отвечать своей жизнью, чтобы всё пережитое и понятое не осталось бездейственным в ней. <...», что «в действительной жизни остаётся эстетическая ответственность актёра и целого человека за уместность игры, ибо вся игра в целом есть ответственный поступок его играющего, а не изображаемого лица-героя». Не стоит забывать, что актёр, его герой и злодейство порой совместимы.

Нельзя не учитывать и то, что процессы карнавализации в России как и сам смех, хоть и имеют сходство с европейской карнавальной традицией, описанной Бахтиным на материале Рабле, тем не менее кардинально отлича- 
ются. Подпольность, саркастичность, уничижительность русского смеха ярко отличает его от европейского карнавального смеха.

Можно увидеть разнонаправленные силы, тормозящие осмысление актёрской профессии в России сквозь призму карнавальной культуры. Первый момент, с нашей точки зрения, исторически связан с представлением о том, что актёр полностью освобождается от обязательств персонажа сразу же после «выхода из роли». Другой подход к театральному искусству, напротив, проистекает из отношения к театру, как к храму, кафедре. Культ театральных подмостков во многом связан с религиозными взаимоотношениями русского человека с церковью, которая считает лицедейство проявлением греховного начала.

Несмотря на то, что профессия «уличный актёр» в России стала оформляться в таковую со времён «Лицедеев» В. И. Полунина, испытывая влияние театральной пантомимы и клоунады, на данный момент существует проблема подделок под европейский уличный театр.

Среди зарубежных бахтиноведов, рассматривающих потенциал идей Бахтина в теории и практике драмы и театра, представляют интерес работы Д. МакКоу, который как театральный практик более тридцати лет посвятил изучению возможностей адаптации теоретических позиций М.M. Бахтина в театральной педагогике. При том, что Д. МакКоу вступает в откровенный спор с позициями Бахтина, делает он это для того, чтобы поставив под сомнение те или иные утверждения Бахтина, по-новому задать традиционные вопросы в отношении самого театра и бахтинских понятий. В целом, сегодня вопрос о возможности применения Бахтинских концептов в профессии актёра остаётся открытым, как и вопрос о том, что сегодня собой представляет уличный театр в России, и существует ли он вообще.

Такова краткая предыстория темы «Бахтин и театр», подготовившая почву для конференции «Уличный театр против театра военных действий» 2019 года.

\section{Летопись конференции 2019 года}

Первый день конференции (16 октября) состоялся в байк-центре "Sexton" мотоклуба «Ночные Волки», где прошло пленарное заседание, посвящённое проблемам развития и трансформации современного театра, развлекательнозрелищных форм и театрального искусства. Участников встречали в духе байкцентра. Гигантских размеров рыба из ржавого железа и череп приглашали гостей пройти в зал.

Если учитывать, что согласно Бахтину диалог допускает скандалы и споры, обман и ложь, - т.е. все, кроме равнодушия, можно сказать, что площадка первого дня конференции полностью соответствовала бахтинскому представлению о диалоге. В 2017 организаторы Международного круглого стола «Проблема хронотопа в современных научных исследованиях» (учредитель круглого стола - ФГБНУ «ИХОиК РАО») проводили второй день 
конференции в байк-центре. Тогда площадка проведения второго дня конференции стала предметом ожесточённой и едкой заочной дискуссии, развернувшейся спустя месяц после проведения конференции на личной странице в Facebook одного известного российского театрального критика, искусствоведа. Эта дискуссия даёт представление о том, как сегодня профессиональное сообщество относится к попыткам прикоснуться к бахтинскому наследию не профессионалов, дилетантов и любителей. Примечательно, что сам искусствовед на конференции не присутствовал, отказавшись от участия после того, как получил от организаторов программу. Итак, обвиняемым в данном случае стали МАНО «Ночные волки» в лице своего лидера А.С. Залдастанова, посягнувшего прикоснуться к святыне.

Одним словом, все острые вопросы на пленарном заседании бахтинской конференции 2019 года были поставлены и заданы в том самом логове Ночных Волков, где в 2017 году проводился второй день бахтинского международного круглого стола, вызвавший споры, критику и неподдельный интерес у научной общественности и у средств массовой информации.

Предлагаемыми темами для дискуссии первого дня конференции 2019 года стали: хлеба и зрелищ: проблемы современного театрализованного политического дискурса; СМИ и современный «театр жестокости; миссия уличного театра в эпоху информационной войны; экспериментальные формы современных перформативных практик; философия поступка М.М. Бахтина в теории и практике современного театра и театрального образования; театр в интернет-коммуникации. Предлагалось обратиться к проблемам современного театрализованного политического дискурса; осмыслить миссию уличного театра в цифровом мире; познакомиться с экспериментальными формами современных перформативных практик; уделить внимание важности идей M.М. Бахтина о философии поступка в теории и практике современного театра и театрального образования.

Основным жанром пленарного заседания стала профессиональная самопрезентация. Академическая наука презентовала себя, субкультура себя, уличный театр себя. Тем не менее диалог состоялся, хотя и не без заочной, но справедливой критики.

Началось пленарное заседание с актуальной темы, касающейся этических вопросов философии поступка в современном мире. Пленарное заседание открылось докладом «Наукометрия vs Академический лейбл: современная российская модель и опыт зарубежных стран - гуманитарные и общественные науки (на примере изучения исследовательской деятельности некоторых университетов России, Великобритании, США)». С данным докладом выступил заведующий кафедрой общегуманитарных и социальных дисциплин, профессор Института современного искусства, главный научный сотрудник Института кино и телевидения, профессор Российского государственного социального университета, доктор искусствоведения Григорий Рафаэльевич Консон. Докладчик отметил минусы и плюсы развития современной россий- 
ской науки. С одной стороны, использование наукометрических инструментов позитивно влияет на российскую науку, с другой стороны, это же во многом и нивелирует её, приводя к попаданию качественных статей российских авторов в зарубежные «хищнические, мусорные журналы» (Материалы международной научно-практической конференции «Уличный театр против театра военных действий». (16-18 октября 2019, Москва), 2019, сс. 23-24).

Тема «философия поступка в современном мире» была также отражена в докладе «Театр пространственного развития против театра военных действий» председателя Экспертного Совета центра Пространственного Развития «Волга-Эксперт», члена Комиссии по вопросам патриотического и духовно-нравственного воспитания детей и молодёжи Совета при Президенте Российской Федерации Алексея Евгеньевича Вайца. Докладич высказал мысль о том, что «театр сегодня может вернуть нас к групповому взаимодействию в социуме, а оттуда уже и к ансамблевости с её социальной динамикой спонтанности» (2019, с. 25), к пространству смыслов. Апробации концептов M.M. Бахтина в практике современного театра и театрального образования были посвящены доклады Юрия Анатольевича Берладина и Елены Александровны Семёновой, Д. МакКоу. Е. А. Семенова в своём выступлении «Верификация концептов М. М. Бахтина в лабораторной работе с актёрами уличного театра в условиях съезда «Смехотворец» поделилась собственными результатами верификации концептов Бахтина. Докладчица привела аргументы в пользу продуктивности попытки реанимировать творческий потенциал личности актёра уличного театра с помощью обращения к феномену русского ряженья, фольклорного театра, балагана» (2019, с. 25). Д. МакКоу представил свою книгу «Бахтин и театр: Диалоги со Станиславским, Мейерхольдом и Гротовским», изданную в 2016 году. Эта книга является первым фундаментальным исследованием, посвящённым анализу потенциала теорий и идей Бахтина в театральной теории и практики (2019, сс. 25-26).

Тема «Хлеба и зрелищ: проблемы современного театрализованного политического дискурса» была представлена докладами Владимира Самуиловича Собкина; Александра Эммануиловича Грефа, Елены Анатольевны Слонимской, Дарьи Сергеевны Пенской; Леонида Григорьевича Николаенко, Эдвисе Вирири.

Доктор психологических наук, профессор, академик РАО, руководитель Центра социологии образования, ФГБНУ «Институт управления образование Российской академии образования» Владимир Самуилович Собкин выступил с докладом «Место СМИ в театрализации массового поведения», подчеркнув, что для Бахтина важен не столько моральный, сколько нравственный закон, что вне нравственных категорий бессмысленно обсуждать поступок и хроноп, который выступает ценностно-ориентированным пространством, наполненным смыслами (2019, с. 26). Далее В.С. Собкин обратился к пониманию драматического и уличного театра, задавшись не праздным вопросом: «Где в уличном театре вешалка? Где он начинается?». 
В своём выступлении «Традиционный театр петрушки и политическое высказывание» художественный руководитель театра «Бродячий Вертеп» А.Э. Греф и актриса театра Е.А. Слонимская познакомили участников конференции со спецификой смеха театра петрушки. Докладчики обратили внимание на то, что, с одной стороны, петрушка аполитичен, с другой стороны, его «интуитивная свобода ставит его в ряд неистребимых оппозиционеров» (2019, с. 27).

В докладе кандидата философских наук Л. Г. Николаенко «Социальнополитические смыслы современного карнавала» прозвучала широко обсуждаемая тема, связанная с рассмотрением карнавала в жестких дуальных оппозициях серьёзной борьбы. Докладчик предложил обратить внимание на карнавал, основой которого является классовая оппозиция между «верхами и низами», определив карнавализацию, как социальный протест, в котором затруднено «осуществление действительных демократических идей» (2019, с. 28). Внимания заслуживает, с нашей точки зрения, наметившаяся линия размышлений докладчика относительно грубого отождествления современных политических процессов с категориями карнавальной культуры. В стендовом докладе Э. Вирири был представлен взгляд на карнавал, как подрывную силу, нарушающую социальные иерархии. Карнавальный акт рассматривался докладчиком в качестве стратегии освобождения на примере правления бывшего президента Роберта Мугабе. Экспериментальным формам современных перформативных практик и уличного театра был посвящён доклад «Социальная ответственность театра и современные практики» доцента кафедры социокультурного развития территории Екатеринбургской академии современного искусства Ольги Алексеевны Стаиной, в котором озвучивались актуальные вопросы: «Что понимать под социальным театром?» и «Прикладным театром»?».

Доклад «Некоторые актуальные катализаторы карнавальных переворотов в практике современного европейского уличного театра» представила на конференции художественный руководитель театра «Странствующие куклы господина Пэжо» (Санкт-Петербург) Анна Шишкина. В процессе показа фото и видео презентации докладчица познакомила участников конференции с различными формами уличного театра, в том числе с творчеством словенского театра «Ljud», французского театра «KaKyet», российским театром «Странствующие куклы господина Пэжо» и др.

Уличный театр «Театр-ЭКС» представил два документальных фильма из своего архива (фильм «Свобода душных улиц» и «Ночной канал», режиссёры - Анна Михайлова и Павел Попов). Режиссёр, художественный руководитель уличного театра «СоЛу» (Санкт-Петербург) Мария Плаксина презентовала свой фестиваль уличных искусства «Улитка» в Санкт-Петербурге.

Анна Владимировна Комарова в докладе «Нравственный аспект философии поступка М. М. Бахтина» затронула педагогическую сторону проблемы поиска смыслов молодым поколением. В качестве примере современного 
воплощения философии поступка, изложенной в работах Бахтина, А. В. Комарова рассмотрела театральную деятельность мотоклуба «Ночные Волки».

Президент мотоклуба «Ночные Волки» Александр Сергеевич Залдастанов показал и прокомментаривал отрывки из своего фильма. Заключительная часть дня включала в себя зрелищную программу. Для участников конференции была организована экскурсия по Байк-центру, которую провёл лидер мотоклуба «Ночные волки» А. С. Залдастанов. На театральной, уличной площадке байк-центра участникам конференции были представлены фрагменты из байк-шоу и новогодних сказок. Завершилась конференция уличным представлением Театра-ЭКС, оснащённым всеми необходимыми атрибутами карнавального зрелища (уличными актерами, восседающими на телегеповозке; пиротехническими фокусами с огнём, всеобщим ликованием со смехом и слезами).

Второй день (17 октября) конференции проходил в диаметрально противоположной атмосфере первого дня конференции, - Центральной научной библиотеки Союза театральных деятелей Российской Федерации. В этот день состоялось два мероприятия: Всероссийский (с Международным участием) семинар «Карнавально-игровой потенциал личности в цифровую эпоху» и первый день Международного круглого стола «Актуальность идей M.М. Бахтина в современном информационном обществе.

Обсуждались такие вопросы как карнавальный архетип художника в цифровую эпоху; влияние информационно-коммуникативных образовательных технологий на выявление карнавально-игрового потенциала личности и развитие художественной одарённости; роль генеративных компьютерных искусств в профессионально-творческом развитии личности; детско-юношеская интернет аддикция; проблемы цифрового неравенства детей и взрослых. В своём приветственном слове заместитель директора по связям с общественностью Центральной научной библиотеки Союза театральных деятелей Российской Федерации Людмила Юрьевна Сидоренко, кандидат культурологии познакомила участников конференции с историей библиотеки, с её уникальными фондами.

С докладами о художественном, творческом развитии личности в контексте идей М. М. Бахтина выступили сотрудники института художественного образования и культурологии РАО.

Открылся семинар докладом главного научного сотрудника института, член-корреспондента РАО, доктора педагогических наук Любови Григорьевны Савенковой «Многоголосье культуры в мире и образование» в котором раскрывались проблемы художественного образования и эстетического воспитания детей и молодёжи в ракурсе идей М. М. Бахтина и Б. П. Юсова.

Доктор педагогических наук, профессор, главный научный сотрудник института Елена Филипповна Командышко в докладе «Событийные коммуникации как механизм общекультурного развития личности» через бахтинские категории «событие» и «со-бытие» раскрыла понятие «событийные коммуни- 
кации», подчеркнув их значимость для ценностно-смысловых ориентиров современных подростков и молодёжи. Сотрудник лаборатории музыки и изобразительного искусства института ФГБНУ «ИХОиК РАО», кандидат искусствоведения Елена Николаевна Пирязева проанализировала с позиции карнавализации гимны известного композитора электронной музыки Карлхайнца Штокхаузена.

Старший научный сотрудник института лаборатории литературы и театра института, кандидат педагогических наук Е. А. Семёнова, заострила внимание на идеях М. М. Бахтина, которые открывают новые возможности постижения природы художественной одарённости и карнавального потенциала личности в норме и патологии. Докладчица обратилась к рассмотрению таких пограничных диагнозов как булимия и анорексия.

Тема доклада доцента кафедры философии КГУ им. А. Байтурсынова Юрия Яковлевича Бондаренко «СМИ в мире сталкивающихся хронопа» во многом пересекалась с темой доклада В. С. Собкина. Бондаренко затронул тему хронотопа, СМИ и карнавализации, отметив, что миф тогда связан с декарнавализацией культуры, когда границы стираются, вследствие чего становится непонятно, что карнавально переворачивать. В подобной ситуации возникает проблема хронотопа, когда сталкиваются различные точки зрения, догадки, доводы и ценностное пространство-время. Наблюдается столкновение хронотопов. В связи с этим, возрастает театральность, постановочность и инсценировка. Стираются границы между доводами и гипотезами. Со-бытие, а не совместное бытие выступает как факт создания бытия.

S. Trausan-Matu обратился к одной из часто обсуждаемых тем - игровым, коммуникативным возможностям искусственного интеллекта, задав актуальные вопросы о том, можем ли мы говорить о карнавале в социальной сети, учитывая, что для Бахтина первостепенное значение в карнавале имеет его телесное воплощение? Могут ли «онлайн-карнавалы» полностью заменить карнавалы «лицом к лицу»?

В докладе M. N. Torres, D. Roychowdhury (Нью-Мехико, США) диалогическая коммуникация Бахтина рассматривалась «как конститутивное определяющее качество человека, являясь противоядием от бандитизма цифровых коммуникаций» $(2019$, с. 47,86$)$.

Третий день конференции проходил в Культурно-просветительском центре "Булгаковский Дом"». Бахтин и Булгаков по-особенному относились к котам. По иронии судьбы, коллаж, который И.П. Уварова-Даниэль и Ю.М. Даниэль подарили М. М. Бахтину, по сию пору хранится в музее М.А. Булгакова в Киеве. Наверное, не случайно и то, что на этом круглом столе произошла встреча представителей театра «Русский стиль» имени M.M. Бахтина и музея-театра «Булгаковский Дом».

Главный режиссёр, художественный руководитель Орловского муниципального драматического театра «Русский стиль» им. М. М. Бахтина, Заслуженный артист России В. И. Симоненко выступил с докладом «Карнавальное 
мышление в точке драматической интеграции: режиссёрская концепция постановочного замысла и решения спектакля по пьесе Н. Эрдмана "Самоубийца"», поставив «вопрос о явном диалогическом конфликте между теоретическими рассуждениями о структурообразующем начале пьесы Николая Эрдмана и её сценическом воплощении в контексте теории карнавала М.М. Бахтина» (2019, с. 43).

Докладчики обращались к вопросам философии языка, анализу литературных произведений, поэзии и драматургии. Эсфирь Иосифовна Гуткина представила доклад «Проблема лирического сюжета в ракурсе эстетики М.М. Бахтина», обратившись к мало разработанной в науке теории лирического творчества М.М. Бахтина, позволяющей, по мнению докладчицы, «трактовать лирический сюжет как один из аспектов диалога, идущего в процессе лирического творчества между поэтом и его героем» (2019, с. 41).

Исследователь и переводчик трудов М.М. Бахтина (на английский и иврит) Сергей Владимирович Сандлер в докладе «Философия поступка и философия языка» обратился к ранней этике и эстетике Бахтина, с его точки зрения повлиявшей «на его более позднюю философию языка». Докладчик высказал мнение, что «ранняя философия Бахтина требовала радикального пересмотра некоторых из самых древних и стойких постулатов философии языка» (2019, c. 43).

Доктор психологических наук Сергей Владимирович Быков в докладе «Формула "не-алиби в бытии" Михаила Бахтина в философии литературы обэриутов» выявил сходство «эстетической философии Бахтина и философии литературы группы ОБЭРИУ» (2019, с. 43).

Руководитель Орловского муниципального научно-просветительского центра имени М. М. Бахтина Александр Юрьевич Титов, поделился перспективами и планами в связи с планируемым открытием в Орле научно-исследовательского бахтинского центра, подчеркнув в своем выступлении религиозный аспект работ М. М. Бахтина.

Игорь Николаевич Чистюхин в докладе «Карнавальная депривация нравственного иммунитета: к вопросу о религиозной апостасии М.М. Бахтина» обратился к термину «депривация». По его мнению, депривация дает возможность взглянуть на амбивалентность как на баланс высокого и низового начала нравственной природы человека.

Доктор философских наук, профессор Всероссийского государственного института кинематографии имени С.А. Герасимова, главный научный сотрудник Государственного института искусствознания Николай Андреевич Хренов выступил с докладом «Театр ХX века выходит из кризиса или реабилитация архаических форм коммуникации». Докладчик отметил, что «возникающий и набирающий силу в первых десятилетиях XX века художественный ренессанс раскалывает культуру на два направления: на более элитарное искусство, <..., и на массовое искусство, получающее выражение в новых видах искусства, в особенности, в кино» (2019, сс. 28-29). 
Исследователь сформулировал шесть стратегий деятельности театра в XX веке, шестая из которых связана с рождением «пропагандистского, агитационного театра, который бы тиражировал идеологические установки, соответствующие новой власти» (2019, с. 29).

Завершился данный круглый стол, и вся конференция показом фотоматериалов из личного архива Ирины Павловны Уваровой легендарного уличного театра «Bread and Puppet» Питера Шумана.

Уличный театр «Bread and Puppet» Питера Шумана концентрирует в себе все озвученные на конференции проблемы, выступая

\begin{abstract}
«симбиозом уличного театрального искусства и политического протеста, который одновременно можно отнести к представителю провокативного театра, к творческой оппозиции и воплощении карнавальной стихии. Однако сам Питер Шуман относил себя к "мятежникам папье-маше, картона и мусора", имеющим «слегка идиотский и несерьёзный вид, обладающих терпимостью, свойственной только сумасшедшим. Шуман подчёркивает "несерьёзность" и “асоциальный статус" этого искусства, который является его привилегией. Те же, кто стыдится его "смехотворного статуса", очевидно, как считает Шуман, либо не уважают это искусство, "либо отражают немощные попытки небескорыстно выдать его за так называемое "серьёзное искусство"» (Семенова, 2020, с. 313).
\end{abstract}

\title{
Сборник трудов конференции
}

В 2020 году был издан сборник трудов конференции, в который вошли доклады и статьи исследователей из городов России (Москва, Санкт-Петербург, Тольятти, Екатеринбург, Омск, Орёл), ближнего и дальнего зарубежья (Минск, Костанай, Киев, Нью-Мехико, Бухарест, Лондон, Беер-Шева, Вассенаар, Копенгаген, Ольборг, Векшё, Ставангер, Бари).

В статьях освящается широкий круг вопросов, заявленных на конференции. Среди обсуждаемых вопросов рассматриваются темы современного бахтиноведения; идеи М.М. Бахтина в междисциплинарном знании; миротворческий потенциал карнавальной культуры и уличного театра; современная медиакультура сквозь призму идей М.М. Бахтина; философия поступка M.M. Бахтина в теории и практике современного театра и др.

Авторы анализируют возможности применения методологии Бахтина в изучении истории литературы, риторики, историзации современности и актуализации истории (A. Gemzoe). В интермедиальной перспективе рассматриваются такие бахтинские понятия как «высказывание», «жанр» и «смех», которые, по мнению исследователей, могут быть определены как некоторые трансмедиальные аспекты творчества Бахтина, сближая тем самым роман, полифоническую форму и карнавализацию культуры и литературы (J. Bruhn). Обсуждается бахтинская теория интонации (N. Andersen). Выделяется несколько возможных направлений применения идей Бахтина в здравоохранении и медицине (Н. Thune). Рассматриваются «модели мира» и выразительность бытия в эстетическом видении М. М. Бахтина», значимость локальных 
моделей мира М. М. Бахтина, позволяющих глубже и многограннее увидеть модели эстетической деятельности человека (Л. П. Печко). Идеи М.М. Бахтина применяются в анализе художественно-тектонической природы искусства (J. Lundquist, E.A. Ротмирова). Проблемы художественного образования и эстетического воспитания детей и молодёжи рассматриваются через сравнительный анализ идей М.М. Бахтина и Б.П. Юсова (Л. Г. Савенкова). Отмечаются минусы развития современной российской науки, в которой использование наукометрических инструментов нивелирует российские исследования (Г.Р. Консон). Авторы критикуют «цифровую революцию», ограничивающую диалогическую коммуникацию (M.N. Torres, D. Roychowdhury).

Во второй главе рассматриваются темы современного бахтиноведения. Невельскому феномену и его влиянию на искусство интерпретации музыкальных текстов И.С. Баха выдающейся пианистки М. В. Юдиной посвящена статья В.В. Ломанович. Э.И. Гуткина рассматривает мало изученную в бахтиноведении проблему лирического сюжета в ракурсе эстетики М.М. Бахтина. С.В. Сандлер обращается к ранней этике и эстетике Бахтина, повлиявшей на его более позднюю философию языка. С.В. Быков сравнивает формулу «неалиби в бытии» Михаила Бахтина с философией литературы обэриутов. В статье Н. А. Меркурьевой через призму архитектоники ответственности M.M. Бахтина анализируется творчество М.М. Пришвина.

В третьей главе «Наследие Бахтина в теории и практике театра» внимание уделено полифоническому, карнавальному и диалогическому потенциалу драмы и театра в контексте взглядов М.М. Бахтина. Дискуссию по данным вопросам с читателями ведут теоретики и практики театра, бахтиноведы из России, Италии и Великобритании (О.В. Гальчук, Ю.А. Берладин, Е.А. Семёнова, B.И. Симоненко, А.Ю. Титов, D. McCaw, S. Petrilli, A. Ponzio).

Четвёртая глава «Метаморфозы театра и развлекательно-зрелищных форм сквозь призму идей М. М. Бахтина» знакомит с архетипическим (карнавальным, игровым) началом театральной культуры, кинопотенциалом театра и его видоизменениями, произошедшими к началу XXI века. Авторы статей данного раздела (искусствоведы, историки культуры, социологи) уделяют внимание наследуемым театрально-игровым традициям и формам, социальной функции театра. В разделе рассматривается этимология театра, многократно повторяющиеся в истории прецеденты реабилитации театра через карнавальные формы (Н.А. Хренов), партисипативные формы зрелища (О.А. Стаина), анализируется интерес к театру современного зрителя (К.К. Ляшев, О. В. Христофорова). В главу вошли статьи философов, социологов, психологов, в которых обсуждаются социальные проблемы развития театрального дискурса, информационных технологий; роль СМИ в мире сталкивающихся хронотопов (Ю. Я. Бондаренко). В статьях также обсуждается проблема деформации и искажения понимания функции карнавала, отождествлением его с социально-политическими процессами, классовой враждой и пр. (Л.Г. Николаенко). 
Пятую главу «Миротворческая миссия карнавальной культуры и современного уличного театра» составили статьи, в которых раскрыт миротворческий потенциал карнавальной культуры и уличного театра (авторы И.П. Уварова, Е.Ю. Кореняк, Я.И. Грушецький, Г.Л. Павленко, Е.А. Семёнова, Ю.А. Берладин, А.Ю. Титов, А.Ю. Павлов).

В шестой главе «Карнавально-игровой потенциал личности в цифровую эпоху» в центре внимания авторов карнавально-игровой потенциал творческой личности. С позиции карнавализации рассматривается электронная музыка XX века (Е.Н. Пирязева), искусственный интеллект и его карнавальнокоммуникативные возможности (S. Trausan-Matu). Внимание уделено карнавальному потенциалу личности в норме и патологии (Е.А. Семёнова); возможностям применения карнавальных форм в обучении студентов в эпоху цифровых технологий (M.N. Torres). В экзистеницальном ключе рассматривается значение таких практик как перформанс и хэппенинг в формировании человеческого самосознания (Г.Л. Тульчинский).

В седьмую главу включена рецензия доктора культурологии, кандидата исторических наук В.М. Воробьёва на сборник докладов и статей «Наследие М.М. Бахтина: культура - наука - образование - творчество» по материалам Международного круглого стола, посвящённого М.М. Бахтину (22 мая 2018 года, Орёл); обзорная статья А.Ю. Титова по итогам этого Всероссийского Круглого стола. Завершает сборник итоговый отчёт Е.А. Семёновой о проведении Международной Бахтинской конференция (16-18 октября 2019, Москва).

\section{Заключение}

Чем больше проходит времени, тем меньше у нас остаётся возможности беседовать с людьми, лично знавшими М.М. Бахтина. 27 января 2021 года в большое время от нас ушла Ирина Павловна Уварова (1932-2021). Ирина Уварова - театровед, театральный художник. Ирина Павловна долгие годы была главным редактором журнала «КукАрт», руководила лабораторией режиссёров и художников театров кукол. Ирина Павловна была лично знакома с М.M. Бахтиным, ездила к нему в Саранск, не раз бывала у него в квартире в Москве. С уходом таких людей как Ирина Павловна, наша связь с Бахтиным все больше переходит в плоскость мифов и косвенных высказываний.

Поэтому, такое, почти ритуальное прохождение сквозь «формальную машину памяти», к которой можно отнести Бахтинские конференции и сборники по их материалам,

«даёт возможность не прерваться преемственности исследовательской традиции, способствуя более интенсивному возобновлению памяти, которая, к сожалению, является элементом искусственным, а потому подвержена воздействию "хаоса и распада"» (Уличный театр против театра военных действий, 2020, с. 14). 
Думается, что восстановление в памяти живого диалога конференции не напрасно, т.к. позволяет подойти к материалам сборника конференции как «к чему-то живому, где бьётся пульс мысли» (Мамардашвили, 2014а, с. 11), избежать ситуации, «когда мы не мыслим точно» (2014b, с. 259).

К счастью, в 2021 году вопреки обстоятельствам, связанным с пандемией вызванной COVID-19, все же состоялось важное событие в области изучения наследия Бахтина - XVII Международная Бахтинская конференция «Идеи Михаила Бахтина и вызовы XXI столетия: от диалогического воображения к полифоническому мышлению» (Саранск, Россия, 05-10 июля 2021 года).

Относительно оценки перспективы будущих бахтинских конференций хочется сказать словами Ю. Тынянова, о важности периодов промежутка, в которых происходит нечто очень важное, и не всегда заметное.

Бахтинские конференции, как думается, нужно оценивать не по принципу удачные они или неудачные, а по тому, дают ли они возможность нам двигаться вперед, человечески расти. Если конференции станут все сплошь грандиозными или «удачными», возможно мы окажемся в ситуации, в которой «оказываются растерянные дети, не знающие что им делать со слишком хорошими игрушками» (Тынянов, 1929, с. 580).

\section{Список литературы}

Бахтин, М. М. (1996). Риторика, в меру своей лживости. Собрание сочинений. Москва: Русские словари.

Бахтин, М. М. (2002). Проблемы поэтики Достоевского 1963. Собрание сочинений (Т. 6). Москва: Русские словари, языки славянской культуры.

Берладин, Ю. А., \& Семенова, Е. А. (б. д.). Деревенский театр (д. Крест). Извлечено от Independent-academy.net website:

http://www.independent-academy.net/about/life/derevensky t.html

Мамардашвили, М. (2014а). Лекции по античной философии. Санкт-Петербург: Азбука, АзбукаАттикус.

Мамардашвили, М. (2014b). Сознание и цивилизация: Выступления и доклады. Санкт-Петербург: Лениздат, Команда А.

Материалы международной научно-практической конференции «Уличный театр против театра военных действий». (16-18 октября 2019, Москва). (2020). Москва: Институт художественного образования и культурологии РАО. Извлечено от http://www.art-education.ru/sites/default/files/u40/sbornik_materialov bahtinskoy_konf erencii_moskva_16-18 oktyabrya_programma_i tezisy_2.pdf

Семенова, Е. А. (2019). Международная Бахтинская конференция «Уличный театр против театра военных действий». Учитель музыки, (4), 20-27.

Семенова, Е. А. (2020). Манифесты уличного театра XX века или мятежникам папье-маше посвящается. Уличный театр против театра военных действий. Сборник научных трудов Международной Бахтинской научно-практической конференции (16-18 октября, Москва, 2019), 310-316. Москва: ФГБНУ «ИХОиК РАО». 
Семёнова, Е. А. (Ред.). (2020). Уличный театр против театра военных действий. Сборник научных трудов Международной Бахтинской научно-практической конференции (16-18 октября, Москва, 2019). Москва: Институт художественного образования и культурологии РАО. Извлечено от www.art-education.ru/sites/default/files/u22/yubileynyy bahtinskiy sbornik_nauchnyh trudov_konferencii_2020.pdf

Тынянов, Ю. Н. (1929). Архаисты и новаторы. Ленинград: Прибой.

Уличный Театр-Экс. (б. д.). Извлечено от http://independent-academy.net/about/life/teatr_eks.html

\section{References}

Bakhtin, M. M. (1996). Rhetoric, in the measure of its falsity. Collected Works. Moscow: Russian Dictionaries. (In Russian).

Bakhtin, M. M. (2002). Problems of Dostoevsky's Poetics 1963. Collected Works (Vol. 6). Moscow: Russian Dictionaries, Languages of Slavic Culture. (In Russian).

Berladin, Y. A., \& Semenova, E. A. (n. d.). Village Theater (v. Cross). Retrieved from Independent-academy.net website: http://www.independent-academy.net/about/life/derevensky t.html (In Russian).

Mamardashvili, M. (2014a). Lectures on Ancient Philosophy. St. Petersburg: Azbuka, Azbuka-Attikus. (In Russian).

Mamardashvili, M. (2014b). Consciousness and Civilization: Speeches and Papers. St. Petersburg: Lenizdat, Team A. (In Russian).

MProceedings of the International Scientific and Practical Conference "Street Theater vs. (October 16-18, 2019, Moscow). (2020). Moscow: Institute of Art Education and Cultural Studies, Russian Academy of Education. Retrieved from

http://www.art-education.ru/sites/default/files/u40/sbornik materialov bahtinskoy konf erencii_moskva_16-18 oktyabrya_programma_i_tezisy_2.pdf (In Russian).

Semenova, E. A. (2019). Bakhtin International Conference "Street theater versus theater of war". Teacher of Music, (4), 20-27. (In Russian).

Semenova, E. A. (2020). Manifestos of the 20th century street theater or papier-mâché rebels are dedicated. Street Theater vs. Theater of War. Proceedings of the International Bakhtin Scientific and Practical Conference (October 16-18, Moscow, 2019), 310-316. Moscow: Institute of Art Education and Cultural Studies, Russian Academy of Education. (In Russian).

Semenova, E. A. (Ed.). (2020). Street Theater vs. Theater of War. Proceedings of the International Bakhtin Scientific and Practical Conference (October 16-18, Moscow, 2019). Moscow: Institute of Art Education and Cultural Studies, Russian Academy of Education. Retrieved from www.arteducation.ru/sites/default/files/u22/yubileynyy_bahtinskiy_sbornik_nauchnyh_trudov_k onferencii_2020.pdf (In Russian).

Tynyanov, Y. N. (1929). Archaists and innovators. Leningrad: Priboy. (In Russian).

Street Theater-Ex. (n. d.). Retrieved from

http://independent-academy.net/about/life/teatr_eks.html (In Russian). 